'Power-by-the-hour': The Role of Technology in Re-shaping Business Strategy at Rolls-Royce

David J. Smith ${ }^{1}$

Nottingham Trent University, Burton Street, Nottingham NG1 4BU, UK

\begin{abstract}
There is a recognised trend of manufacturing companies offering not only products, but services and even complete solutions to business problems. Research has highlighted economic, market demand and competitiveness factors as responsible for the re-shaping of business strategies that this has involved. This study analyses the extent to which another factor, technology, has been a significant factor in the switch from product oriented to service oriented strategies. A case study of the aero engine manufacturer Rolls-Royce is used to analyse the impact of technology, which is found to have led manufacturers to re-shape their business strategies. The study finds that developments in one technology in particular, namely digital electronics, have been a powerful enabling factor facilitating the implementation of service strategies. This provided original equipment manufacturers (OEMs) like Rolls-Royce with a competitive advantage relative to conventional service providers, by enabling them to acquire new knowledge management capabilities.
\end{abstract}

Keywords: Aerospace, business strategy, innovation, services, technology

Pre-publication copy published in Technology Analysis and Strategic Management, 25 (8) pp987-1007. DOI 10.1080/09537325.2013.823147

\footnotetext{
${ }^{1}$ Email: david.smith02@ntu.ac.uk
} 


\section{'Power-by-the-hour': The Role of Technology in Re-shaping Business Strategy at Rolls-Royce}

\section{Introduction}

The management literature urging manufacturers to make the transition from supplying products to supplying products and services on an integrated basis is very extensive (Oliva and Kallenberg, 2003). In terms of industry sectors, the literature that has highlighted and analysed this trend extends mainly to capital goods, including computing, cranes, trains, and aerospace (Howells, 2004).

The logic behind manufacturers moving forward along the value chain to include the provision of services as well as manufacturing is normally attributed to three main determinants: economic factors, demand conditions and competitive advantage (Oliva and Kallenberg, 2003). The economic argument is that through the provision of services additional revenue can be generated from an installed base of products especially if the product life cycle is a long one with products remaining in service for many years. To reinforce this it is also pointed out that services typically yield significantly higher margins than products. The case for demand conditions is that as customers become more sophisticated so their expectations rise and they demand solutions rather than mere products. Often this is set in terms of the trend towards greater specialisation and a move on the part of many companies to outsource services as they focus on core competences (Pralahad and Hamel, 1990). Finally the case for competitiveness rests on the notion that services are often more difficult to imitate and therefore are a source of potential competitive advantage.

However very few studies have looked at alternative perspectives. For instance there has been little consideration of what one would intuitively expect to be an important driver behind this trend towards the provision of services, namely technology. One might well argue that such has been the attention given by strategy researchers to concepts like core competences (Pralahad and Hamel, 1990), that technology, particularly long term technological change has taken something of an analytical back seat, when it comes to analysing the forces that shape business strategy. This study 
attempts a re-assessment. The study looks specifically at the part that technology plays as a factor in the transition from products to services, especially the move towards offering integrated solutions using new business models. The aim is to analyse the role of technology in re-shaping the business strategy of manufacturers as they extend their product offerings. The study seeks to answer a single research question - what role did technology play in re-shaping business strategy in the aero engine sector? Here the focus is on the industry environment (Grant, 2008: 66) and how this has changed as a result of macro-level factors, specifically developments in technology and the resulting response from manufacturers in terms of revising and reshaping their business strategy. To answer this question the study analyses recent developments in the aero engine sector of the aerospace industry through a case study of a company often cited as an example of a manufacturer leading the way in offering not merely services, but integrated solutions, namely Britain's largest manufacturing company, the aero engine manufacturer, Rolls-Royce.

\section{Review of the Literature}

The trend towards manufacturing companies moving into the provision of services was first highlighted in the 1980s by Vandermerwe and Rada (1988: 315), who coined the term 'servitization' to describe the phenomenon. The provision of services is now a conscious and explicit strategy for many firms, resulting in a steady flow of research papers analyzing this trend with a variety of terms used to describe it. Baines et al. (2009: 522) refer to it as 'product-service strategy' and Howells (2004: 25), noting the way services are sometimes bundled as a 'wrapper' complementing products, uses the term 'service encapsulation'. Wise and Baumgartner (1999), Davies (2004) and Windahl et al. (2004) on the other hand note that the move into services sometimes involves very much more than simply bundling the provision of complementary services along with the product. They use the term 'integrated solutions' to describe a business model where services are typically not an add-on to a product, rather products and services are combined to address specific customer needs.

A key feature of the integrated solutions business model is that it is about much more than just moving down the value chain to provide services as well as products. With this business model manufacturers typically 'take over the risks and responsibilities of performing activities previously handled in-house by their customers' (Davies, 2004: 
732), and in exchange for providing much greater value, they get a significantly higher return. Risk in this context refers to the possibility of a product mal-function leading to a potential loss of service, and the responsibility is to fix it ensure there is no loss of service. Assuming a level of risk implies more than providing additional services since services are being provided on a quite different basis, leading to the use of terms such as 'performance-based contract' (Kim et al., 2007) and 'outcome-based contract' (Ng et al., 2009) to describe packages where the customer is buying not merely services along with a product but, 'a predetermined level of availability to meet the customer's objectives' (Kim et al., 2007: 1844). What is provided goes well beyond replacing the sale of goods, with the sale of goods plus support services. With such contracts the integrated solution typically extends to the service provider agreeing to carry out all necessary maintenance and guaranteeing a given level of product availability and performance, at a fixed price normally based on usage.

Davies (2004) suggests that the trend towards the provision of outcomes is particularly a feature of capital goods producers. Given that capital goods tend to have a comparatively long life, this has led some researchers to use expressions like 'long term service agreement' (Kerr and Ivey, 2001: 290) and 'through-life management' (Ward and Graves, 2007: 457) to describe the provision not merely of products but support services for them over the course of their life.

According to Wise and Baumgartner (1999) the particular attraction of servitization for capital goods manufacturers is that it allows them to make use of their installed base comprising the total number of their products currently in use. For capital goods manufacturers whose products are durable and have a relatively long lifespan, this is typically many times greater than the value of their annual sales of products. As examples Wise and Baumgartner (1999) cite trains (i.e. locomotives), civil aircraft and tractors, where the installed base is ten or more times greater than annual sales.

The inclusion of aerospace is no coincidence as several studies have looked at servitization in the aerospace sector. These range from studies that mainly cite aerospace as an example of this trend, to ones that provide a more detailed analysis of the factors at work and the impact on the firms. Among the former are studies by Baines et al. (2009), Davies et al. (2006), Howells (2004), Neely (2007) and Oliva 
and Kallenberg (2003), which note how engine manufacturers like General Electric and Rolls-Royce now provide engine maintenance on an hours flown basis, and studies by $\mathrm{Ng}$ et al., (2009) and Kim et al. (2007) which use airframe maintenance as an example of the provision of performance based maintenance.

Four studies (Johnstone et al., 2009; Kerr and Ivey, 2001; Lorrell et al., 2000; and Ward and Graves, 2007) specifically analyse the move to servitization in the aerospace industry. Johnstone et al. (2009) provide an in-depth case study that analyses how one engine manufacturer has moved into the provision of services. It broadly confirms Oliva and Kallenberg's (2003) findings from other sectors noted earlier in this paper, that the three factors leading to servitization are economic factors, customer demands and the pursuit of competitive advantage. The authors (Johnstone et al., 2009) pinpoint two of these three factors, namely economic factors in the form of cost pressures, and the need to provide a stronger customer focus given the trend towards greater use of outsourcing. They also note that implementation creates challenges in terms of gaining employee involvement and the integration of different parts of the organisation. A study by Ward and Graves (2007) surveyed eleven companies operating in different parts of the aerospace supply chain. It identified four factors behind servitization. Three were those noted by Oliva and Kallenberg (2003). The additional fourth factor identified by Ward and Graves (2007) was risk, specifically a desire to push the risks associated with revenue streams, down the supply chain. The authors noted that this factor was less significant than the other three. Ward and Graves (2007) also highlighted the importance of information systems in implementing this kind of service. Significantly Ward and Graves (2007) like Johnstone, Dainty and Wilkinson (2009) said little about the part played by technology, in providing information in the first place. In contrast, an earlier study by Lorrell et al. (2000), while noting the importance of the factors identified by Oliva and Kallenberg (2003), also cited industry specific institutional changes, in the form of market de-regulation, as an important driver particularly in the commercial sector. This they argued had caused manufacturers to re-think the way they do business. The study cited the move into services as a direct consequence of institutional changes, though it said little about the strategies of particular companies. 
The most comprehensive analysis of servitization in the aerospace sector is that by Kerr and Ivey (2001). It focuses specifically on the aero engine sector and provides extensive contextualisation covering not only institutional changes but other changes affecting the sector in general and maintenance services in particular. A feature of the study is the attention it gives to economic factors especially the economics of engine maintenance. It also highlights the crucial importance of knowledge of engine performance characteristics in the provision of maintenance services, particularly the scope such knowledge provides for accurately predicting maintenance requirements and optimising engine performance. To this end the study notes that engine data is increasingly becoming available on a real time basis through the development of engine monitoring systems, and the authors highlight the implications of this for the engine manufacturers. However relatively little is made of the part played by technology in facilitating this, nor does the study consider the wider implications of this for the strategies employed by the engine manufacturers.

Overall the studies of the aerospace industry support and reinforce Oliva and Kallenberg's (2003) general perspective on servitization that there are three main factors acting as drivers for servitization, namely economic factors, customer demands and the pursuit of competitive advantage. The studies identify a small number of additional factors contributing to servitization, namely risk (Ward and Graves, 2007), institutional changes (Lorrell et al., 2000) and the increased availability of information (Kerr and Ivey, 2001), but none of the studies identifies any of these factors as being particularly important.

Significantly none of the studies specifically cites technology, especially advances in technology, as a driver for servitization. One might argue that the study by Kerr and Ivey (2001) comes close because it did note how increased knowledge of product performance is becoming available through the development of engine health monitoring systems. However the study said nothing about the technologies that are helping to make this possible. In the light of this, and the way in which studies of servitization in aerospace like studies of other sectors have ignored advances in technology, as a possible factor behind servitization, this study seeks to rectify this omission. 


\section{Methodology}

A case study methodology was selected for two reasons. Firstly, because Eisenhardt (1989) argues that case study research focuses on the dynamics present in a given setting or context, and the focus of the study was factors influencing the re-shaping of strategy in a specific industry context. Secondly because Voss et al. (2002) maintain that case study research is particularly appropriate for analysing changes in technology, and the impact of technology was a theme running throughout the study.

Following Leonard-Barton (1990) a 'dual' methodology was used for data collection, involving both archival materials and interviews, both public and private in nature. The former were largely publicly available archival materials and reliance on them was justified on the grounds that Lazonick and Prencipe (2005), who have researched aerospace extensively, maintain that with company level research on strategy, much can be achieved with such materials.

The archival materials included a range of documentary sources. They consisted of documents published by the case company together with a range of specialist published materials covering aviation in general and the aerospace industry in particular. Among the case company documents consulted were annual reports from 1970 to the present, the in-house quarterly magazine published by the case company from 1979 to the present, together with a range of reports that included technical summaries and market reports. The specialist published materials included both printed and online resources. Of these, the most used item was the searchable online digital archive of the specialist aviation periodical Flight International, which is available from 1909-2009. This provided a number of contemporary reports (Lewis, 1999; Paddon, 1988) on developments in engine technology. Other specialist aviation periodicals consulted included Aviation Week and Space Technology (Terino, 2005), Aerospace (Baldwin, 1993; Robins, 1994; Ruffles, 1986), Air International (Walters, 1999) and Airways (Davis, 2010). This was supplemented by further data, much of it technical in nature from specialist technical publications. These included material from the trade press such as Military and Aerospace Electronics (Wilson, 2003) which had been identified from online databases including Business Source Complete and ScienceDirect, and reports, lectures and other materials published by the principal 
professional body in the UK dealing with aviation, the Royal Aeronautical Society (Howse, 2004: Robins, 2004).

Alongside these documentary sources a number of specialist texts were used covering various aspects of aviation. These fell into two broad categories, those that were essentially of a technical nature and those that were largely historical. The former included several works covering a variety of aspects of engine technology (Gunston, 1995; Kay, 2007; Miller and Sawers, 1968; and Rolls-Royce, 1966), while the latter included biographies (Hooker, 1984; and Rowe, 2005); corporate histories (Donne, 1981; Pugh, 2002); and studies of the aviation industry (Bluestone et al., 1981; Langewiesche, 2010; and Whitford, 2007).

The use of a number of different types of document served to ensure the quality of the evidence used. The various types of document used were written either by specialist technical authors and journalists with many years' experience, including a number who had previously worked in the industry often in a technical role, or by senior technical figures working for the case company, with extensive personal knowledge of the technologies and technological advances detailed in the case study.

The data gathered in this way was corroborated and verified through a small number of interviews conducted using the key informant approach, a technique widely used in ethnographic studies (John and Reve, 1982; Phillips, 1981). Five key informants were interviewed, having been selected not on a random basis but specifically because they occupied, or had until recently occupied, senior roles within the aerospace industry. This meant that they had specialised knowledge of the issues being researched (Kumar et al., 1993). They included a commercial director, a business development manager, a new product development manager, a finance director and an aerospace industry consultant. Four had been employed by companies that were partners of the case company on joint ventures or partnerships for major engine programmes at some point during the period covered by the case study. One had had worked as a contractor to the case company for many years. The interviews were in Marshall and Rossman's (1989: 94) terminology, 'elite interviews' with respondents well qualified to comment on the case company's strategies, as well as industry trends and practices. Identification of the sample of key informants followed a snowballing 
strategy similar to that outlined by Healey and Rawlinson (1991: 346), whereby having interviewed 'one good senior contact' that individual's personal network proved very effective in identifying further suitable key informants. The interviews which were semi-structured lasted between 40 and 90 minutes and were recorded and transcribed. Four were conducted face-to-face while one was a telephone interview.

Having amassed a substantial body of data in this way it was then subjected to content analysis (Bryman and Bell, 2007) using a simple manual coding system based on critical incidents in relation to the development of aero engine technology. From this a timeline tracing the historical path of advances in engine technology was produced, which in turn formed the basis of the narrative for the detailed in-depth case study. In terms of analysis, the archival materials provided the initial basis for the development of the case study. The key informant interviews were then used to triangulate the emerging picture of developments within the case company and to evaluate the extent to which new technologies had contributed to the re-shaping of business strategy within it.

\section{Case study: Rolls-Royce plc}

\subsection{Jet Engine Technology}

The jet engine that forms the powerplant of today's modern jet airliner is a gas turbine made up of three main elements, a compressor, a combustor and a turbine (see figure 1). While the first jet engines were turbojets, since the 1960s more efficient turbofan designs have been used. These have an inlet fan at the front which both draws air into the compressor and sends some into a bypass duct around the engine in order to cool it, reduce noise and generate a significant proportion of engine power. The function of the compressor, which comprises rows of ever smaller rotating blades on a central shaft (Scranton, 2011) is to compress the incoming air. The high pressure air is then mixed with atomised fuel and burnt in the combustor. This produces very hot gases which expand rapidly and are forced out of the back of the engine under intense pressure to provide the thrust which propels the aircraft forward (Rolls-Royce, 1966). On the way the exhaust gases drive a multi-stage turbine rotating at high speed which powers the compressor. The power generated is measured in pounds of thrust and early jet engines produced only limited thrust, typically less than 10,000lbs. 


\section{Insert Figure 1}

Although the jet engine was readily taken up by the military in the years immediately after World War Two for applications such as interceptor fighters (Geels, 2006), largely because of its performance in terms of power to weight, it was more than a decade before jet airliners became anything like a serious proposition for the world's airlines. The cause of the delay was that although jet travel offered passengers the twin potential benefits of speed and comfort, the development of the jet airliner in the early years was held back by two key factors, namely poor fuel economy and poor durability (Geels, 2006). Early jet engines used a lot of fuel. Specific fuel consumption (sfc) on the first generation of turbojet engines was about $0.9 \mathrm{lb} / \mathrm{hr} / \mathrm{lb}$, making them significantly less fuel efficient than the piston engines they replaced (see figure 2). Although simpler than piston engines by virtue of replacing a reciprocating motion with a rotating motion, jet engines also required more maintenance than equivalent piston engines, by virtue of their novelty and their high operating temperatures (Miller and Sawers, 1968: 178) which demanded new and unproven materials. General Electric's J-47 engine for example, admittedly a military rather than a commercial engine, went for only 500 hours between overhauls even in the mid-1950s (Miller and Sawers, 1968: 186). Poor durability meant that mechanical parts like turbine blades had to be replaced after a short time, a serious problem for commercial airlines in view of the high levels of usage demanded of their aircraft.

Key factors in improving engine performance in terms of fuel economy were the bypass ratio, the pressure ratio and turbine inlet temperature (TET). As a base line Rolls-Royce's first generation turbofan engine the RCo12 Conway which powered both British and American airliners in the 1960s had a bypass ratio of 0.3:1, a pressure ratio of $15: 1$ and an operating temperature of $1,050^{\circ} \mathrm{C}$ (see table 1). To improve fuel efficiency engines needed to operate at higher temperatures and higher pressures so as to ensure fuel was turned into energy as efficiently as possible. Improving durability required a combination of factors including the development of stronger heat resistant materials, more effective design and improved manufacturing processes. 
Insert Table 1

$* * * * * * * * * * *$

$* * * * * * * * * * * *$

Insert Figure 2

$* * * * * * * * * * * *$

\subsection{Advances in Engine Technology}

Over the last 40 years successive generations of new engine have introduced advances in engine technology that have progressively improved not only engine performance but engine durability. Rolls-Royce's RCo42 Conway engine which entered service in the 1960s included one significant innovation designed to boost durability, over first generation turbojets. Although the compressor utilized what were then conventional extruded aluminium blades (Howse, 2004), the Conway pioneered the use of forged nickel alloy turbine blades incorporating internal air cooling (Gunston, 1989, Hooker, 1984: Whitford, 2007), which significantly extended the life of turbine blades.

The successor to the Conway (Donne, 1981) was the Rolls-Royce RB211, a very much larger and more powerful high bypass turbofan engine, that powered the first wide-bodied airliners like the Lockheed L-1011Tristar and Boeing 747. Entering service in the early 1970s, it was designed to operate under more demanding conditions, including a much higher 5:1 bypass ratio, twice the pressure ratio and an operating temperature of $1,250^{\circ} \mathrm{C}$ higher. It was more than twice as powerful as the earlier Conway and significantly more fuel efficient (see figure 2). It also incorporated a number of technological advances designed to improve durability. Following the lead given by its American rivals General Electric and Pratt and Whitney, Rolls-Royce switched from forged to cast turbine blades, manufactured using the 'lost wax' process (Hooker, 1984). Substituting investment casting for forging not only allowed harder alloys to be used it also facilitated more effective and reliable internal cooling of turbine blades, resulting in them being significantly more durable. The 524 variant, a later and more powerful version of the RB211engine also incorporated film cooled turbine blades enabling them to operate at even higher temperatures, while the 535 variant used a new 'directionally solidified' blade (Howse, 2004: 12) that was both stronger and more durable. 
Later versions of Rolls-Royce's 535 engine, designated the 535E4 that entered service in the late 1980s (Walters, 1999), saw the introduction of one of the most significant advances in engine technology (Robins, 1994), the hollow titanium wide chord blade fitted to the large fan at the front of the engine. Hitherto engine manufacturers had used narrow solid titanium blades. These suffered a number of disadvantages. They were heavy, a large number of them were needed and they required a mid-span support or snubber to prevent vibration. This significantly reduced aerodynamic efficiency. Rolls-Royce's introduction of the much lighter and stronger hollow titanium wide chord fan (Prencipe, 2001) on the E4 version of its 535 engine, produced by an entirely new process of diffusion bonding (Howse, 2004: 18), resulted in a fan that was much lighter and much stronger (see figure 3). Many fewer blades were required, 22 as opposed to 33 on earlier versions (Baldwin, 1993), and it dispensed with a mid-span support, resulting in a significant (4\%) improvement in fuel efficiency (see figure 2). Being wider and stronger the blades were also more robust and durable resulting in less susceptibility to bird strikes and foreign object damage (FOD).

Rolls-Royce's latest generation of engine, the Trent and its associated variants that entered service in the late 1990s and 2000s on the new generation of large twin jet airliners like the Airbus A330 and Boeing 777, introduced further advances in technology associated with design, materials and manufacturing processes, which again resulted in improvements not only in fuel efficiency (see figure 2) but particularly in engine durability. These included turbine blades made from advanced single crystal titanium alloys which eliminate the grain boundaries which reduce the life of conventionally cast blades (Owen, 2001: 132) and the introduction of thermal barrier coatings (Howse, 2004: 12). These advances in technology combined with improvements in internal cooling mean that turbine blades can now operate at $1,800^{\circ} \mathrm{C}$ while the base material only has a temperature capability of $1,350^{\circ} \mathrm{C}$. Another development with later versions of the Trent was the introduction of swept fan blades. Introduced on the Trent 900 engine that powers the Airbus A380 the swept fan requires fewer blades and significantly increases damage resistance and durability by centrifuging debris away from the engine core and down the bypass duct (Howse, 
2004: 18). These changes mirrored similar developments at its rivals General Electric and Pratt and Whitney.

With the development of ultra high-thrust engines like the Rolls-Royce Trent in the 1990s, manufacturers were forced to develop engine control systems capable of handling a much greater number of engine parameters (Brusoni and Prencipe, 2001), as the hydro-mechanical engine control systems used up until this point, as one commentator (Paddon, 1988: 33) put it at the time, 'just could not cope.... they were becoming mechanical monsters'. As a result Rolls-Royce and the other leading engine makers who developed similar ultra-high thrust engines introduced full authority digital electronic control (FADEC) systems, which were fundamentally different from earlier engine control systems. Data on engine parameters, such as turbine temperature, fan speed, and altitude was now collected via electronic sensors in the form of transducers and thermocouples and communicated electronically to a computer which managed all aspects of engine performance. This mirrored the development of fly-by-wire (FBW) control systems for aircraft, described by Langeweische (2010: 99) as, 'a marriage between electrical control circuits and digital computers'.

The switch to digital electronics provided a number of benefits, particularly in terms of engine durability and reliability. Firstly FADEC systems record any deviations from the ideal operating range of the engine, thereby facilitating more effective maintenance. Secondly they 'treat the engine very gently' (Paddon, 1988: 34) meaning that because a FADEC system is constantly monitoring a large number of engine parameters it can make minute adjustments to the engine, thereby ensuring it is functioning as close to its ideal operating conditions as possible, so as to minimize wear and tear on components. Finally a FADEC system provides valuable system protection within the engine, so as to protect components from damage wherever possible thereby ensuring durability.

The cumulative effect of advances in engine technology meant that by the 1990s when the first of the current generation of engines like the Rolls-Royce Trent entered service they not only exhibited a level of performance in terms of thrust and fuel efficiency (see table 1) that was a very substantial improvement on 30 years earlier, 
their durability was also vastly improved compared to first generation turbofans like the Rolls-Royce RCo42 Conway. The extent of this improvement was reflected in the demand for spares to replace worn and damaged components. Even in the early 1980s a jet engine would consume a quantity of spares equivalent to the original value of the engine in about eight years (Whitford, 2007), but engines like the new RollsRoyce Trent that entered service at the end of the 1990s consumed this quantity of spares, not in eight years, but 25 years. For the engine makers this represented a very big drop in demand for spares and therefore their revenues.

\subsection{Re-shaping Business Strategy: From Product-centric to Customer-centric}

The dramatically reduced demand for spares brought on by advances in technology presented a particularly challenging problem for engine manufacturers like RollsRoyce. With the profit margin on spares estimated to be seven times higher than that on new engines (Markillie, 2009), it wasn't just a matter of the loss of revenue but the loss of their most profitable revenue. Faced with this, Rolls-Royce began to revise and re-shape its business strategy. Hitherto Rolls-Royce's business strategy, like that of its American rivals Pratt and Whitney and General Electric, was a 'product-centric' strategy (Davies, 2004: 733), that aimed to maximise the breadth of its product portfolio. By having the widest possible range of engines it aimed to offer the largest number of airframe applications for its engines thereby maximising the number of potential airline customers who could use its products. Not only that, having developed advanced technologies, such as its innovative hollow titanium wide chord fan, Rolls-Royce could then apply them to different types of engine. As figure 3 shows the wide chord fan initially developed for the 535E4 variant of the RB211, was also fitted to Rolls-Royce's 524 engine that powered the Boeing 747, the V2500 that powered the Airbus A320, A321 and A319 and the Tay engine that powered the Fokker F70 and the Gulfstream business jet. This 'dual use' (Ruffles, 1986; Robins, 2004) approach to new technologies served to spread R \& D costs across different engine programmes leading to economies of scope (Swann, 2009).

$* * * * * * * * * * * *$

Insert Figure 3

$* * * * * * * * * * * *$ 
Rolls-Royce's vigorous pursuit of this product-centric business strategy meant that whereas in 1980 it sold engines for just four civil airframe applications, by 1996 this had risen to 27 (Rolls-Royce, 1997: 8) and as figure 4 shows deliveries of commercial engines which at the start of the 1990s had been around 400 per year had trebled to more than 1200 per year by the start of the new millennium. By the early 2000s the company had even displaced one time market leader Pratt and Whitney (Bluestone et al., 1981) to take second place in the worldwide market for aero engines (Lazonick and Prencipe, 2005) just behind arch rival General Electric.

$* * * * * * * * * * *$

Insert Figure 4

$* * * * * * * * * * *$

However just at the point when Rolls-Royce's product-centric business strategy was finally yielding success, the company like its rivals, General Electric and Pratt and Whitney, began to feel the impact of the cumulative advances in engine technology, in particular the cumulative improvements in engine durability. Faced with this, in the 1990s Rolls-Royce, while continuing to pursue a broad product portfolio, began to re-shape its strategy along the lines of what Davies (2004: 732) terms a 'customercentric' business strategy. This aimed to extract greater value from one of the company's most important assets, namely its installed engine base. This greater value was to come from offering not merely spare parts, but maintenance services as well, though offered on a very different basis from conventional MRO services with fixed price contracts linked to guarantees of engine availability.

Historically Rolls-Royce, along with other OEMs had undertaken maintenance, repair and overhaul (MRO) work on a fairly minor scale. Indeed one study observed that, 'until the 1990s, repair and overhaul of its engines was not viewed as a mainstream activity' (Pugh, 2002: 194). The OEMs limited their exposure to MRO to warranty work in the early part of an engine's life (see figure 5), leaving the market to the inhouse engineering divisions of major airlines and independent MRO providers. The latter had become a more important part of the MRO market as airlines increasingly outsourced their maintenance work in order to focus on their core business. When outsourced in this way, MRO work was undertaken on a 'time and materials' basis 
(Ward and Graves, 2007: 467) where the contract price was determined by actual costs in terms of staff time and spare parts used.

$* * * * * * * * * * *$

Insert Figure 5

$* * * * * * * * * * *$

In 1993, Rolls-Royce took its first tentative steps towards a customer-centric strategy with the setting up of a separate company, Rolls-Royce Aero Engine Services Ltd, designed to pool together the repair and overhaul facilities that had hitherto operated independently at sites in Derby, Bristol, Coventry and Scotland in the UK and overseas in Canada and Brazil. The company then set about putting in place an appropriate infrastructure with which to deliver MRO services on a global basis. Additional facilities for repair and overhaul work were acquired around the world, chiefly through a succession of joint ventures with airlines (see table 2). By 2001, this expansion had grown the company's repair and overhaul business from a modest \$400million in 1993 with just six sites of which two were overseas, to \$1.6billion (Pugh, 2002) with 16 sites around the world (Wilson, 2003). Thus over an eight year period Rolls-Royce created the infrastructure to enable it to offer MRO services on a worldwide basis, with major facilities across the world.

$* * * * * * * * * * *$

Insert Table 2

$* * * * * * * * * * *$

However reorganisation of its repair and overhaul operations was only a one part of the company's new customer-centric strategy. A key part of re-shaping the company's business strategy was extracting significantly more value from its installed base of engines. To do this Rolls-Royce developed a completely different type of service offering. Rather than services provided on a conventional 'time and materials' basis like its competitors the in-house engineering divisions of the bigger airlines and the independent MRO providers, Rolls-Royce broke new ground by offering its customers an 'integrated solution' (Wise and Baumgartner, 1999: 138) in the form of 
fixed price maintenance based on engine availability. This new type of performance based service contract was initially marketed as 'power-by-the-hour'.

\subsection{Power-by-the-hour for the US Navy}

An example of the new style performance based contracts being offered by RollsRoyce was its contract with the US Navy signed in September 2003 (Rolls-Royce, 2005a) for the provision of maintenance and logistical support for the Rolls-Royce Turbomeca F405 Adour engines that powered the navy's 200 strong fleet of Boeing/ BAE Systems T-45 Goshawk advanced naval jet trainer aircraft.

Under the terms of the contract Rolls-Royce was to be the sole provider of logistics support, receiving a fixed price for each hour the engines were in the air. This meant Rolls-Royce providing all the engine maintenance, support, trouble-shooting, parts supply and logistics support for the aircraft at three naval air stations in Meridian in Mississippi, Kingsville in Texas and Patuxent River in Maryland. Performance was measured almost exclusively against the fleet metric of providing a minimum level of ready-for-issue (RFI) engine availability, which previously had averaged 70 per cent, meaning that aircraft were out of action for nearly one third of the available time. As part of the new contract Rolls-Royce guaranteed an improved RFI engine availability rate of 80 per cent.

For the US Navy, the switch to performance-based maintenance contracts of this type, offered three potential benefits. Firstly it meant that as the aircraft operator it avoided the uncertainty of unpredictable breakdowns and repair costs. Instead maintenance became a known and certain fixed cost against which it could plan. The second potential benefit was an improved level of service, manifest in increased RFI engine availability and therefore flying time. Finally these services were now provided at a lower cost.

$* * * * * * * * * * * * *$

Insert Figure 6

$* * * * * * * * * * * * * *$

The success of the initial one year contract, led to a significant improvement in maintenance quality and performance reliability, with all the performance metrics 
being met. As a result the US Navy exercised its option to renew the contract for a further four years. Two years into the contract in 2005, the program manager for the US Navy's Undergraduate Flight Training Systems at Patuxent River, Maryland, commented that RFI engine availability on the T-45 Goshawk trainers had risen above the target rate of 80 per cent in the initial year reaching 85 per cent, while the average time between engine removals had increased from 700 hours to over 900 hours and the expected engine removal rate had fallen by 15 per cent (Terino, 2005). As Captain Daniel Ouimette, Commodore of Training Air Wing ONE, commented, 'Before signing the contract with Rolls-Royce we had aircraft on the ground because of engine availability, but this has never happened under the new regime' (Rolls-Royce, 2005b: 19).

It wasn't only in operational terms that Rolls-Royce's power-by-the-hour contract proved beneficial to the US Navy, there were financial gains as well. The contract brought significant cost savings over the previous arrangements. As figure 6 shows in the contract's first three years the Navy's savings amounted to \$15 million, \$18 million and \$5 million respectively (Kratz, 2008), with total savings over the five year life of the contract projected to total $\$ 61$ million. In 2008, upon the conclusion of the fifth year of the contract, a new expanded five year contract was signed, worth \$90million per year (Rolls-Royce, 2009) on similar terms but under the MissionCare $^{\mathrm{TM}}$ label, the new name for Rolls-Royce's aftermarket services for the Defence sector.

\subsection{The Growth of Aftermarket Services}

The contract with the US Navy is typical of the performance based contracts that Rolls-Royce now provides as part of its range of enhanced aftermarket services. In the civil aviation sector these services are offered as TotalCare ${ }^{\circledR}$, comprising a range of packages that allow airlines to select from a menu of aftermarket services on an agreed scale of costs per flight hour. In these deals Rolls-Royce maintains the airlines' engines on a planned maintenance basis on behalf of the customer (Rolls-Royce, 2003: 13). Similar arrangements are available in the defence and corporate sectors offered as 
MissionCare $^{\mathrm{TM}}$ and CorporateCare ${ }^{\circledR}$ respectively. In each instance the services form a comprehensive set of through life engine maintenance arrangements.

To support these service packages in March 2004 Rolls-Royce opened an Operations Centre at its Derby headquarters, capable of remotely monitoring an airline customers' engines on a 24-hour basis (Rolls-Royce, 2005a). It provides an integrated decision support system, coordinating data from aircraft, engine and overhaul shops with logistics support and engineering knowledge. The Operations Centre maintains the 3,500 engines that Rolls-Royce has under management whether on the ground or in the air, on a real time basis via telemetry systems. Thus if an engine's performance falters for any reason while it is airborne, this will be picked up by the Operations Centre. Staff at the Operations Centre can then pull up the engine's history and mobilise appropriate maintenance resources on the ground ready to service the aircraft when it lands.

$* * * * * * * * * * * * *$

Insert Figure 7

$* * * * * * * * * * * * *$

The growth of aftermarket services such as the new style performance based maintenance contracts, resulted in increased revenue for Rolls-Royce. By delivering integrated solutions, the company was providing significantly more value. No longer was it just a spare parts supplier, it was now providing a range of maintenance and repair services as well. The increased revenue that these services brought in was reflected in a significant increase in the proportion of Rolls-Royce's total revenue derived from services.

20 years ago in 1991 services represented just 25 per cent of the company's total revenue (Rolls-Royce, 2002: 17). By 2000 the proportion of revenue derived from services had risen to over a third (Rolls-Royce, 2001: 12), representing 37.5 per cent of its total revenue of $£ 5.56$ billion. Although part of the growth was accounted for by finance and leasing activity, nonetheless a significant proportion was accounted for by repair and overhaul work. This had doubled in value over the previous five years (Rolls-Royce, 2001: 12). By 2011, revenue from services had continued to grow reaching $£ 6.02$ billion, and amounting to more than half (53.4 per cent) of RollsRoyce’s total revenue (Rolls-Royce, 2012: 13) of $£ 11.28$ billion (see figure 7). 


\subsection{Changing Competitive Positions in the Market for Aftermarket Services}

Aftermarket services in the form of MRO had traditionally been provided by the airlines themselves, by independent firms or by the OEMs. MRO was something that historically all three engine manufacturers had collectively neglected over the years. Indeed the traditional view in the sector had been, '... if you have a Chevrolet, you don't take it back to Detroit to fix it' (Lewis, 1999: 54), but by the 1990s all three manufacturers were starting to 'recognise lifecycle opportunities'. With the OEMs keen and able to increase their share of this market through the provision, as the US Navy example illustrates, of better and more effective maintenance, changes in the competitive positions of the service providers resulted. Hence by 2003 it was being reported that, 'the trend has been for airlines to increase outsourcing, original equipment manufacturers (OEMs) to increase their share of MRO work, and independents to increasingly disappear' (Wilson, 2003: 4).

In reality the picture was a little more complex. Not all airlines chose to outsource their MRO work to OEMs. Doganis (2006: 285) notes that some of the larger international carriers saw in MRO, 'the potential value of these activities as profit generators in their own right'. As a result carriers like Lufthansa in Europe and Singapore Airlines in Asia, 'set about transforming what were previously internal departments into specialist companies'. However such instances tended to be the exception rather than the rule. Most small and medium sized airlines were too small to provide all the MRO services economically, especially as the greater technological sophistication of modern jet engines required them to invest in increasingly sophisticated maintenance equipment and more highly trained staff. For such carriers outsourcing MRO made economic sense. It also allowed them to focus on their core activities, something that military customers like the US Navy also preferred to do.

It was a similar story with the new and rapidly expanding low cost carriers (LCCs) like Ryanair (Barratt, 2004) and easyJet (Jones, 2005). Given their business model which relied on keeping processes simple and costs low (Holloway, 2008), LCCs were keen to lower their direct operating costs, with the result that they sought to outsource as many activities as possible and maintenance was an obvious choice. By so doing they could avoid, 'top-heavy maintenance administration, or costly hangars 
and maintenance facilities of their own' (Doganis, 2010: 142), and the OEMs were well placed to take on the MRO work being outsourced in this way. The Irish LCC Ryanair was typical. In 2004 it announced that it was outsourcing the maintenance and overhaul of all the CFM56-7 series engines powering its fleet of Boeing 737-800 aircraft to GE Engine Services as part of a10 year contract involving a maintenance cost per hour system (Professional Engineering, 2004: 12).

Independent MRO firms found themselves increasingly squeezed. The introduction of a new generation of technologically more sophisticated and reliable engine in the early 2000s provided what Wilson (2003: 4) described as, 'a double hit on independent shops - higher investment and lower demand'. Higher investment was required because of the new technologies being used, such as FADECs, while the decline in demand was the product of airlines switching to OEMs. As the general manager of one independent noted, 'the OEMs are trying to gain a larger share of the market by buying or co-venturing with independents or putting them out of business' (Wilson, 2003: 5).

Hence in the last 10 years we have seen the OEMs gain market share at the expense of the airlines and the independents especially. These changes in competitive position were largely attributable to advances in technology. New technologies made it possible for OEMs, by virtue of the data they were now able to collect and analyse regarding their engines, to offer a better and more effective service, while at the same time making it harder for small and medium airlines and independents to compete on the same terms, a situation compounded by the introduction of new business models by the LCCs.

\section{Analysis}

Rolls-Royce was not alone in feeling the impact of a significant drop in the demand for spares. The two other engine manufacturers with the capacity to produce a full range of civil and military engines, Rolls-Royce's American rivals, General Electric and Pratt and Whitney, were faced with very similar issues in terms of the decline in the demand for engine spares. 
As the case study shows General Electric and Pratt and Whitney had also contributed significant advances in engine technology, both in terms of new manufacturing processes and component improvements. Consequently by the 1990 s they too were feeling the impact of the steady and continuous improvements in engine performance both in terms of efficiency and durability. As one commentator explained, 'by designing and producing ever more reliable and competitive powerplants, engine manufacturers have fallen victim to their own success' (Lewis, 1999: 54). A similar theme was echoed at General Electric. Brian Rowe, former head of GE Aircraft Engines speaking of the new ultra high thrust GE90 engine that came into service in the late 1990s commented, ' ... the engines just seem to run forever' (Rowe, 2005: 144). It was a similar story at Pratt and Whitney where Jim Keenan, senior vice president of commercial engines noted in 2003 that, 'today's generation of engine enters the shop nominally about one third as often as a typical engine 25 years ago' (Wilson (2003: 5).

Rolls-Royce was perhaps the first to feel the impact of the improvements in engine durability, because having only recently increased its share of the world market for commercial engines from 10 per cent in the mid-1980s to 30 per cent in the late-1990s (Pugh, 2002: 306) its installed engine base was relatively 'youthful'. As such its installed engine base included a higher proportion of newer and therefore more durable engines with a much lower spares requirement.

Nonetheless by the late 1990s all three manufacturers had launched new large diameter, wide chord fan engines for the new generation of large twin jet airliners being introduced by Boeing and Airbus. These engines all incorporated the latest technology including FADEC electronic control systems, with the result that all three saw a decline in their most profitable revenue stream - replacement parts. This led all three to take a new perspective on maintenance, repair and overhaul work (MRO)

However, as one commentator noted at the time, 'General Electric, Rolls-Royce and Pratt and Whitney have taken slightly different approaches to the changing MRO market, although all three are seeking a greater share of the pie' (Wilson, 2003: 6). While Rolls-Royce' relied on joint ventures with international airlines particularly ones from Asia, General Electric, having first consolidated its Engine Services 
department and its Commercial Spare Parts operation into a single organisation, General Electric Aircraft Engine Services (GEAES), utilized a series of take-overs designed to complement its existing facilities in California and Kansas in the US and create a worldwide engine service network. It purchased British Airways engine overhaul facility at Cardiff in Wales (Pugh, 2002; Rowe, 2005), followed by the purchase of Greenwich Air Services in the US, a 70 per cent stake in Malaysia Airlines' Aero Engines Repair and Overhaul (AERO), a 20 per cent stake in EVA Airways' Evergreen Aviation Technologies in Taiwan and a 95 per cent stake in the engine service arm of the Brazilian airline Varig (Lewis, 1999: 55). Pratt and Whitney on the other hand, took a different approach again. As the former market leader with 90 per cent market share in the 1960s it already had an established worldwide network of some two dozen existing MRO facilities around the world (Markillie, 1999) and it used these facilities to create five specialist engine overhaul and repair centres (Wilson, 2003: 6).

But it was not merely a case of the engine manufacturers doing more MRO work. A report at the end of the 1990s noted, 'manufacturers are not looking simply to develop and extend their geographical coverage, but also the commercial scope of their aftersales activity’ (Lewis, 1999: 54). Bill Vareschi, president of GE Engine Services described the new services as, 'We're bringing airlines new procedures and processes that optimise workscope, lower the cost of operations and reduce the time taken for engine repair and overhauls' (Lewis, 1999: 54). Extending the scope of their aftermarket activities meant General Electric followed Rolls-Royce in offering services like on-wing support, maintenance hours agreements and total care packages alongside conventional repair and overhaul services. Pratt and Whitney followed too, leading one independent MRO provider to note, 'the OEMs are selling total repair, power-by-the-hour packages; that's the strategy on all new engines coming out of the OEMs' (Wilson, 2003: 6).

Hence the re-shaped business strategy developed by Rolls-Royce and described in the case study had by the decade of the 2000s, been adopted by all three of the main engine manufacturers that dominate the aero engine sector, and in each instance technology was a powerful influence in the re-shaping of business strategy. 
Signs of a similar trend in other sectors are limited. Technologies very similar to those employed in the aero sector, involving remote monitoring, have been introduced in Formula 1 motor racing. Groups of technicians located at a team's headquarters often on the other side of the world, closely monitor each racing car's systems during races to ensure optimum performance and maximise the chances of winning. But this remains a very limited and highly specialised application. Such technologies have yet to be used more generally in the automotive industry, where institutional factors mean that maintenance and repair services remain the province of the dealer network (Maxton and Wormald (2004). Servitization is however found in sectors producing high value, long lived capital goods. Examples include manufacturers of trains, mobile communication systems and flight simulators. But in these instances a study by Davies (2004) suggests that changes of strategy are the product not of advances in technology but changing customer demands.

\section{Conclusions}

While much has been written about the movement of manufacturers into services, this study breaks new ground by considering the contribution of technology to this process. At the outset a single question was posed. What role did technology play in inducing the aero engine manufacturer Rolls-Royce to re-shape its business strategy? The principal finding is that in Rolls-Royce's case advances in technology played a very important part in the company's decision to re-shape its business strategy utilizing servitization.

The advances in technology were not major technological discontinuities (Tushman and Anderson, 1986) or radical in character, resulting in what Christensen (1997: xiii) terms 'disruptive innovation'. Rather the advances in technology were the product of cumulative incremental innovations in materials, design and manufacturing, that formed 'sustaining technologies' (Christensen, 1997: xv) that helped to foster improved performance in established products along lines valued by mainstream customers.

The improved performance focused on greater durability and reliability, and reduced the demand for spares which had long been the company's most profitable revenue stream. This led Rolls-Royce to look to servitization to make up for this loss and the 
case study shows that technology was a powerful enabling factor facilitating the move to servitization in this sector. Technology, particularly developments in digital electronics in the form of FADEC systems, transformed the scope of the maintenance services provided by the engine manufacturers. The engine health monitoring capabilities made possible by the introduction of electronic FADEC systems facilitated the introduction of service innovations such as fixed price per hour maintenance contracts.

While the study suffers from the limitation that one cannot generalize from a single case, nonetheless it is evident from the analysis section of this study that as far as the aero engine sector is concerned Rolls-Royce was not an isolated case. Not unsurprisingly in this highly oligopolistic sector, Rolls-Royce's rivals, General Electric and Pratt and Whitney, were similarly affected and followed broadly similar strategies, though it was generally Rolls-Royce that led the way certainly in terms of some of the service innovations that resulted from greater knowledge of engine performance data.

What the case study lacks in terms of scope for generalization, like many cases studies (Stake, 1995), it makes up for in the value of the insights it provides. In particular there are a number of important implications that follow from this study. The first is in terms of the provision of a better quality service. In the past where MRO was concerned there was a mis-alignment between the interests of OEMs and users of their products. For the former, MRO was an important source of profit because of the high prices charged for replacement parts, while for the latter MRO was a cost that ate into profit. Now, as providers of fixed price maintenance services it is very much in the OEMs' interest to take every opportunity to learn where and how things go wrong and revise and improve their products, so as to reduce the cost of providing repairs and maintenance, something that is similarly in the interests of users.

Secondly, the enormous amount of data on engine performance that is now available in real time thanks to FADEC systems, presents new opportunities when it comes to the development of new services. The challenge is to develop appropriate knowledge management techniques to utilize this data. This will require OEMs to develop new 
areas of expertise, and it is interesting to note that Rolls-Royce has set up a joint venture with Data Systems and Solutions, a subsidiary of US-based Science Applications International Corporation (Hutchinson, 2003) in order to expand its expertise in the area of aftermarket information systems. 


\section{References}

Baines, T.S., Lightfoot, H.W., Benedetti, O and J.M. Kay. 2009. The servitization of manufacturing: A review of the literature and reflections on future changes. Journal of Manufacturing Technology Management 20, no.5: 547-567.

Baldwin, B. 1996. In search of the wide chord. Aerospace September 1993: 18-19.

Barratt, S.D. 2004. The sustainability of the Ryanair model. International Journal of Transport Management, 2, No 2: 89-90.

Bluestone, B., Jordan, P. and M. Sullivan. 1981. Aircraft Industry Dynamics: An Analysis of Competition, Capital and Labor. Boston, MA: Auburn House Publishing.

Bryman, A. and E. Bell. 2007. Business Research Methods. $2^{\text {nd }}$ edition, Oxford: Oxford University Press

Brusoni, S. and A. Prencipe. 2001. Unpacking the Black Box of Modularity: Technologies, Products and Organizations. Industrial and Corporate Change 10, no.1: 179-205.

Christensen, C.M. 1997. The Innovator's Dilemma: When New Technology Causes Great Firms to Fail. Boston, MA: Harvard Business School Press.

Davies, A. 2004. Moving base into high-value integrated solutions: a value stream approach, Industrial and Corporate Change 13 no.5: 727-756.

Davies, A., Brady, T. and M. Hobday. 2006. Charting a Path Toward Integrated Solutions, MIT Sloan Management Review 47 no.3: 39-48.

Davis, E. 2010. BOAC and the Rolls-Royce 707. Airways, April 2010: 32-45.

Doganis, R. 2006. The Airline Business, $2^{\text {nd }}$ edition ,Routledge, London.

Doganis, R. 2010. Flying off Course: Airline Marketing and Economics, $4^{\text {th }}$ edition, Routledge, London.

Donne. M. 1981. Leader of the Skies: Rolls-Royce - The First Seventy-Five Years. London: Frederick Mueller.

Eisenhardt, K.M. 1989. Building Theories from Case Study Research. Academy of Management Review, 14 no.4: 532-550.

Geels, F.W. 2006. Co-evolutionary and multi-level dynamics in transitions: The transformation of aviation systems and the shift from propeller to turbojet (19301970). Technovation 26: 999-1016.

Grant, R.M. 2008. Contemporary Strategy Analysis. $6^{\text {th }}$ edition, Oxford: Blackwell, Gunston, B. 1989. Rolls-Royce Aero Engines. Sparkford: Patrick Stephens Limited. 
Gunston, B. 1995. The World Encyclopaedia of Aero Engines. Sparkford: Patrick Stephens Limited.

Healey, M. J. and M.B. Rawlinson. 1991. Interviewing business owners and managers: a review of methods and techniques. Geoforum 24 no. 3: 339-355.

Holloway, S. 2008. Straight and Level: Practical Airline Economics, $3^{\text {rd }}$ edition, Ashgate: Aldershot.

Hooker, S. 1984. Not Much of an Engineer. Shrewsbury: Airlife Publishing

Howells, J. 2004. Innovation, Consumption and Services: Encapsulation and the Combinatorial Role of Services. The Service Industries Journal 24 no.1: 19-36.

Howse , M. 2004. Aero gas turbines: an ever-changing engineering challenge, Whittle Lecture 2004, $3^{\text {rd }}$ February 2004. London: Royal Aeronautical Society.

Hutchinson, J. 2003. Turning Data into Solutions, The Rolls-Royce Magazine, 96, March 2003: 26-29.

John, G. and T. Reve. 1982. The Reliability and Validity of Key Informant Data from Dyadic Relationships in Marketing Channels. Journal of Marketing Research 19: 517-524.

Johnstone, S., Dainty, A. and A. Wilkinson. 2009. Integrating products and services through life: An Aerospace experience, International Journal of Operations and Production Management 29 no.5: 520-538.

Jones, L. 2005. easyJet: The story of Britain's biggest low cost airline, Aurum Press: London.

Kay, A. L. 2007. Turbojet, History and Development 1930-1960, Vol. 1 Great Britain and Germany. Marlborough: Crowood Press.

Kerr, C.I.V. and P.C. Ivey. 2001. A strategic review of the large civil aero engine market and the paradigm shift to a service. The Aeronautical Journal, May 2001: 287293.

Kim, S-H., Cohen, M. A., and S. Netessine. 2007. Performance Contracting in AfterSales Service Supply Chains Management Science 53 no.12: 1843-1858.

Kratz, L. 2008. Maintaining Competition in Defense Sustainment, Paper presented at the $5^{\text {th }}$ Annual Acquisition Research Symposium: Creating Synergy for Informal Change, Monterey, CA, $14^{\text {th }}-15^{\text {th }}$ June.

Kumar, N., Stern, L.W. and J.C. Anderson. 1993. Conducting interorganizational research using key informants. Academy of Management Journal 36 no.6: 16331651. 
Langewiesche, W. 2010. Fly by Wire: The Geese, the Glide and the Miracle on the Hudson. London: Penguin Books.

Lazonick, W. and A. Prencipe. 2005. Dynamic capabilities and sustained innovation: strategic control and financial commitment at Rolls-Royce plc. Industrial and Corporate Change, 14 no.3: 501-542.

Leonard-Barton, D. 1990. A dual methodology for case studies: synergistic use of a longitudinal single site with replicated multiple sites. Organization Science, 1 no.3: 246-266.

Lewis, P. (1999) Rule change, Flight International, $27^{\text {th }}$ January- $2^{\text {nd }}$ February: 54-55.

Lorrell, M., Lowell, J., Kennedy, M. and Levaux, H. 2000. Cheaper, Faster, Better? Commercial Approaches to Weapons Acquisition. Santa Monica, CA: Rand Corporation,

Markillie, P. 2009. Britain's lonely high flyer. The Economist. $1^{\text {st }}$ October 2009: 6062.

Marshall, C. and G.B. Rossman. 1989. Designing Qualitative Research. London: Sage.

Maxton, G.P. and Wormald, J. 2004. Time for a Model Change: Re-engineering the Global Automotive Industry, Cambridge University Press: Cambridge.

Miller,R. and Sawers, D. 1968. The Technical Development of Modern Aviation. London: Routledge \& Kegan Paul.

Neely, A. 2007. The Servitization of Manufacturing: An Analysis of Global Trends. $14^{\text {th }}$ European Operations Management Association Conference, $17^{\text {th }}-20^{\text {th }}$ June 2007, Ankara, Turkey.

Ng, I.C.L., Maul, R. and N. Yip. 2009. Outcome-based contracts as a driver for systems thinking and service-dominant logic in service science: Evidence from the defence industry. European Management Journal 27: 377-387.

Oliva, R. and P. Kallenberg. 2003. Managing the transition from products to services in goods-dominant firm. International Journal of Service Industry Management, 14 no.2: $162-172$.

Owen, J.M. 2001. Developments in Aeroengines. Pertanika Journal of Science and Technology. 9 no.2: 127-138.

Paddon, L. 1988. Active-control engines, Flight International. $9^{\text {th }}$ July 1988: 33-34.

Phillips, L.W. 1981. Assessing measurement error in key informant reports: a methodological note on organizational analysis in marketing. Journal of Marketing Research 18 no.4: 395-415. 
Pralahad, C.K. and G. Hamel. 1990. The Core Competences of the Corporation. Harvard Business Review, May-June 1990: 79-91.

Prencipe, A. 2001. Exploiting and Nurturing In-house Technological Capabilities: Lessons from the Aerospace Industry. International Journal of Innovation Management 5, no.3: 299-321.

Professional Engineering. 2004. GE to do Ryanair's maintenance, Professional Engineering. 17, no. 19, $10^{\text {th }}$ November 2004: 12.

Pugh, P. 2002. The Magic of a Name, Part Three: A Family of Engines. Duxford: Icon Books.

Robins, R. 1994. Enterprise and innovation. Aerospace February 1994: 8-13.

Robins, R. 2004. Striving for perfection. Rolls-Royce plc Centenary Lecture. $4^{\text {th }}$ November 2004. London: Royal Aeronautical Society.

Rolls-Royce. 1966. The Jet Engine. $2^{\text {nd }}$ edition, Derby: Rolls-Royce Ltd.

Rolls-Royce 1997. Annual Report 1996. London: Rolls-Royce plc.

Rolls-Royce. 2001. Annual Report 2000, Rolls-Royce plc, London

Rolls-Royce. 2002. Annual Report 2001. London: Rolls-Royce plc.

Rolls-Royce. 2003. Annual Report 2002. London: Rolls-Royce plc.

Rolls-Royce. 2005a. Annual Report 2004. London: Rolls-Royce plc.

Rolls-Royce. 2005b. The sky's the limit. The Rolls-Royce Magazine 105 June: 15-19.

Rolls-Royce. 2009. Rolls-Royce as US Navy Missioncare contract leads to $\$ 90$ million award. Press Release $28^{\text {th }}$ October 2009. London: Rolls-Royce plc.

Rolls-Royce 2012. Annual Report 2011. London: Rolls-Royce plc.

Rowe, B.H. 2005. Power to Fly: From de Havilland Apprentice to Chairman of General Electric Aircraft Engines. Barnsley: Pen and Sword Aviation.

Ruffles, P.C. 1986. Reducing the Cost of Aero Engine Research and Development. Aerospace November 1986: 15.

Scranton, P. 2011. Mastering failure: technological and organisational challenges in British and American military jet propulsion, 1943-57. Business History 53 no.4: 479504.

Stake, R.E. 1995. The Art of Case Study Research, Sage Publications, Tousand Oaks, CA. 
Swann, G.M.P. 2009. The Economics of Innovation: An Introduction. Cheltenham: Edward Elgar.

Terino, J. 2005. R-R Seeks to Expand Power-By-The-Hour Work. Aviation Week \& Space Technology. $13^{\text {th }}$ June. (Accessed at http://www.aviationweek.com/aw/generic/story_generic.jsp?channel=aerospacedaily \&id=news/R06135.xml)

Tushman, M.L. and Anderson, P. 1986. Technological Discontinuities and Organisational Environments. Administrative Science Quarterly. 31 no. 3: 439-465.

Vandermerwe, S. and J. Rada. 1988. Servitization of business: adding value by adding service. European Management Journal 6 no.4: 315-324.

Voss, C., Tsikriktsis, N. and M. Frohlik. 2002. Case research in operations management. International Journal of Operations and Production Management 22 no.2: $195-219$.

Walters, B. 1999. Rolls' Biggest fan. Air International. February 1999: 115-118.

Ward, Y. and A. Graves. 2007. Through life management of the provision of total customer solutions. International Journal of Service Technology and Management 8 no.6: 455-477.

Whitford, R. 2007. Evolution of the Airliner. Marlborough: Crowood Press.

Wilson, J.R. 2003. Jetliner maintenance moves to electronic monitoring. Military and Aerospace Electronics July 14 no.7: 1-10.

Windahl, C., Andersson, P., Bergren, C. and C. Nehlor. 2004. Manufacturing firms and integrated solutions: characteristics and implications. European Journal of Innovation Management, 7 no.3: 218-228.

Wise, R. and P. Baumgartner. 1999. Go Downstream: The New Profit Imperative in Manufacturing, Harvard Business Review, September-October: 133-141.

11.09.2012 
Figure 1

Schema of a Modern Jet Engine

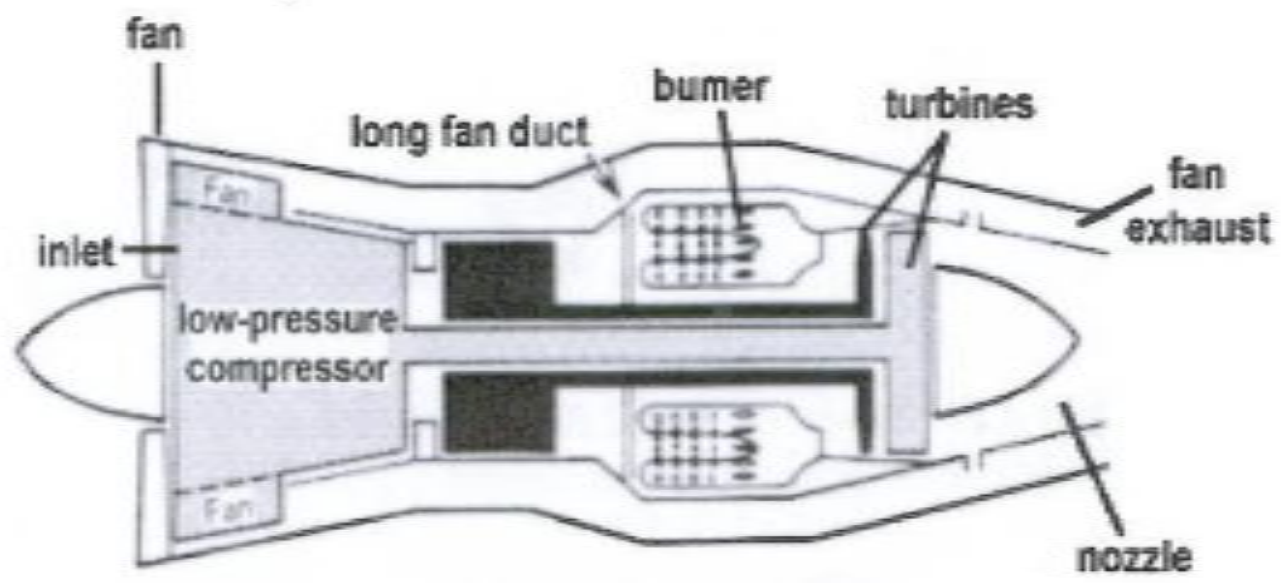


Figure 2

Improvements in Specific Fuel Consumption of Civil Jet Engines 1950-2000

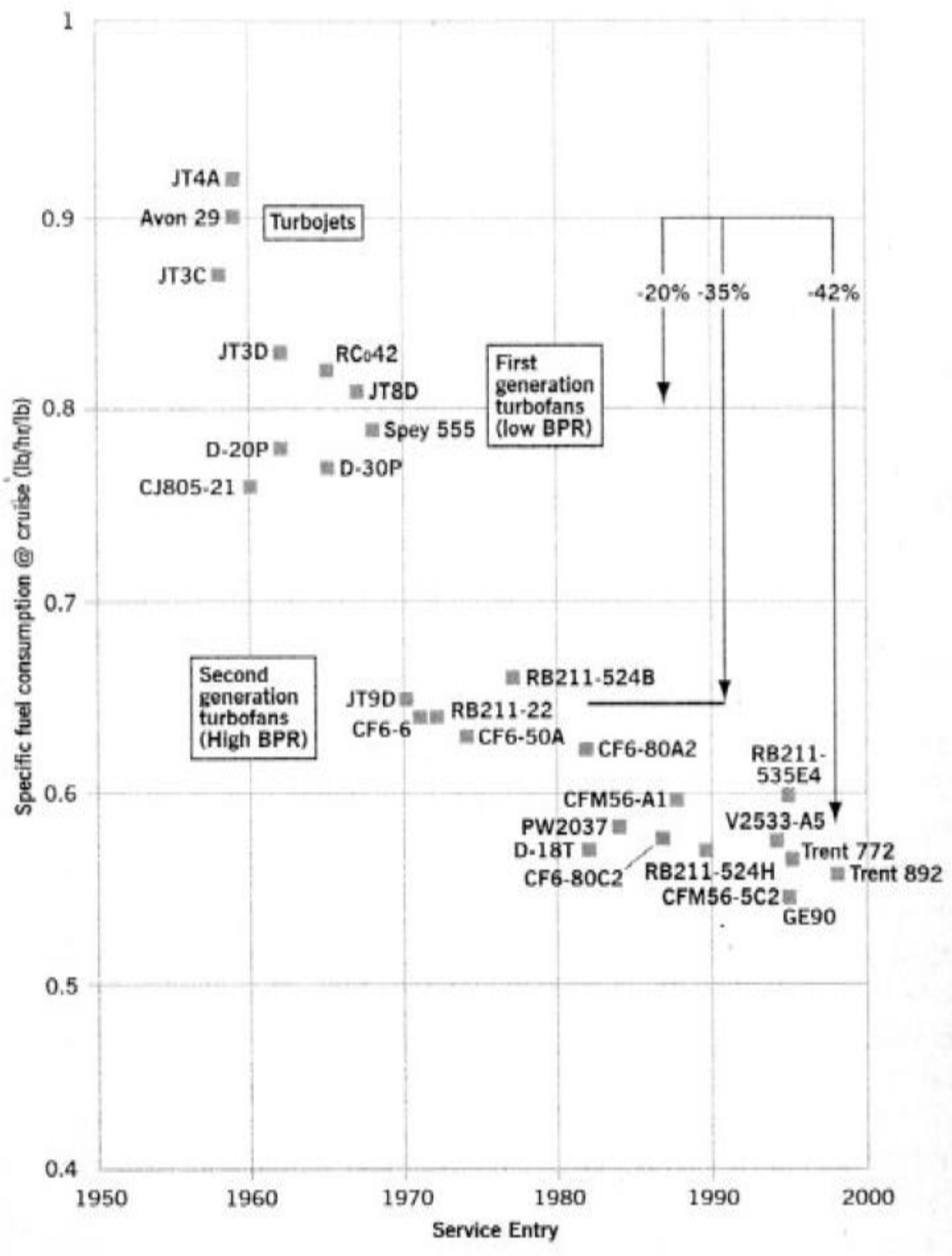

Source: Whitford (2007: p116) 
Figure 3

Applications of Wide Chord Titanium Fan Blade Technology

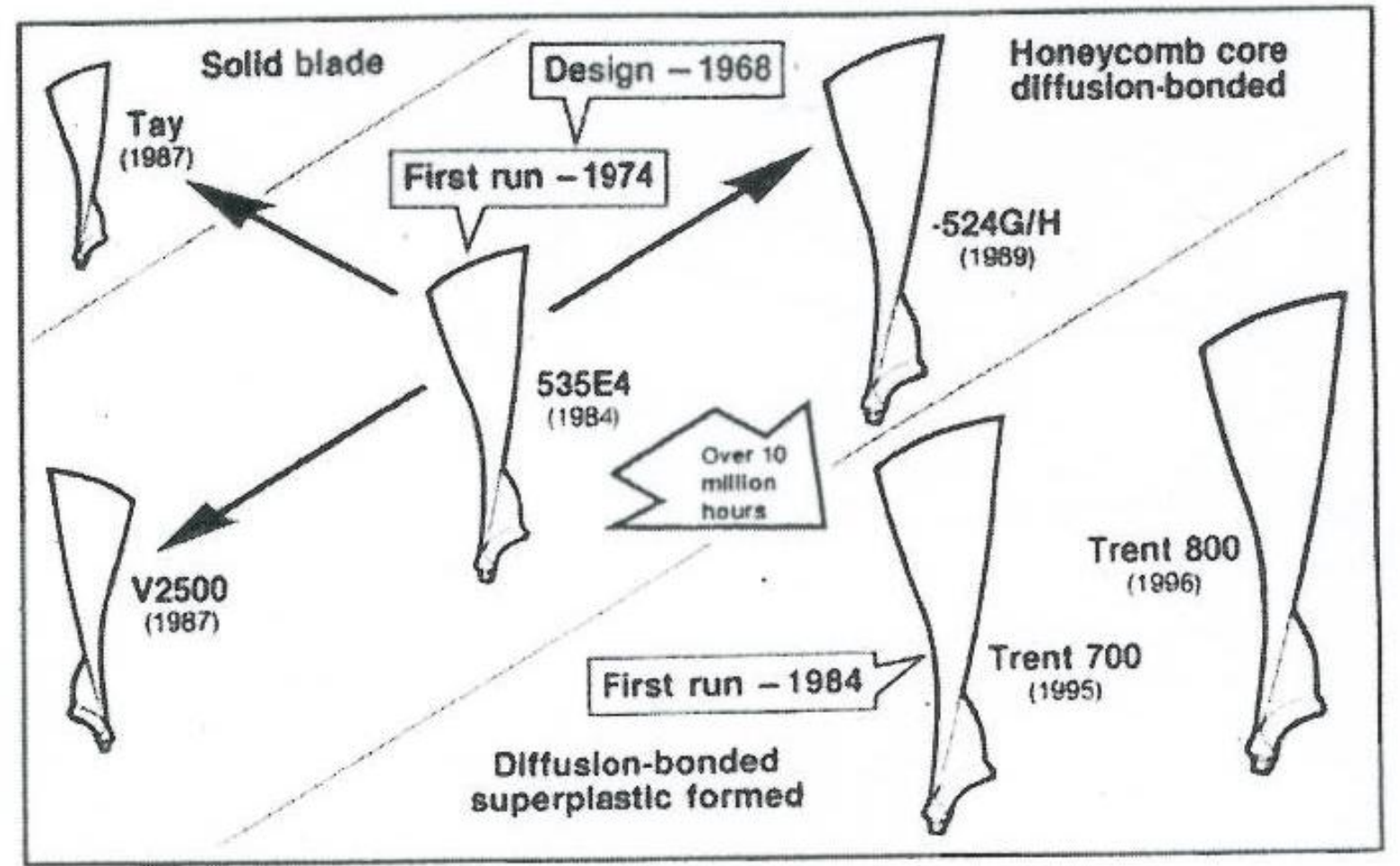

Source: Baldwin (1993)

Figure 4

Annual Deliveries of Rolls-Royce Civil Engines 1995-2010

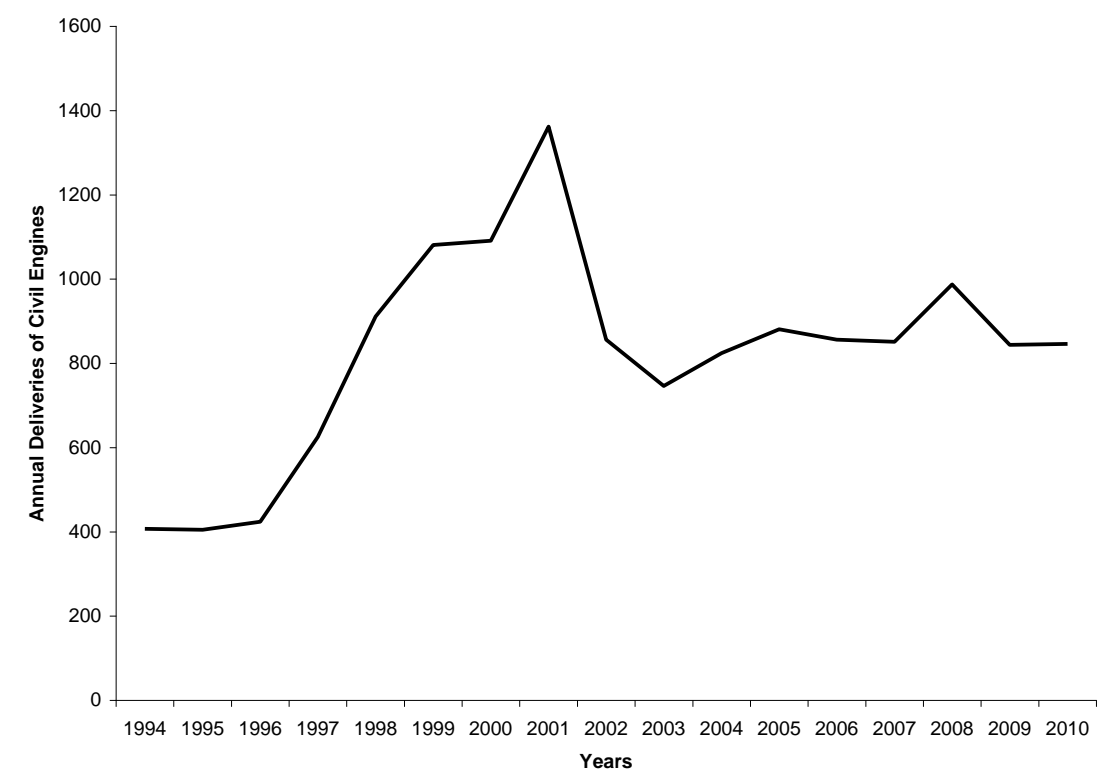

Source: Rolls-Royce Annual reports 1998-2010 
Figure 5

Aftermarket Competitiveness

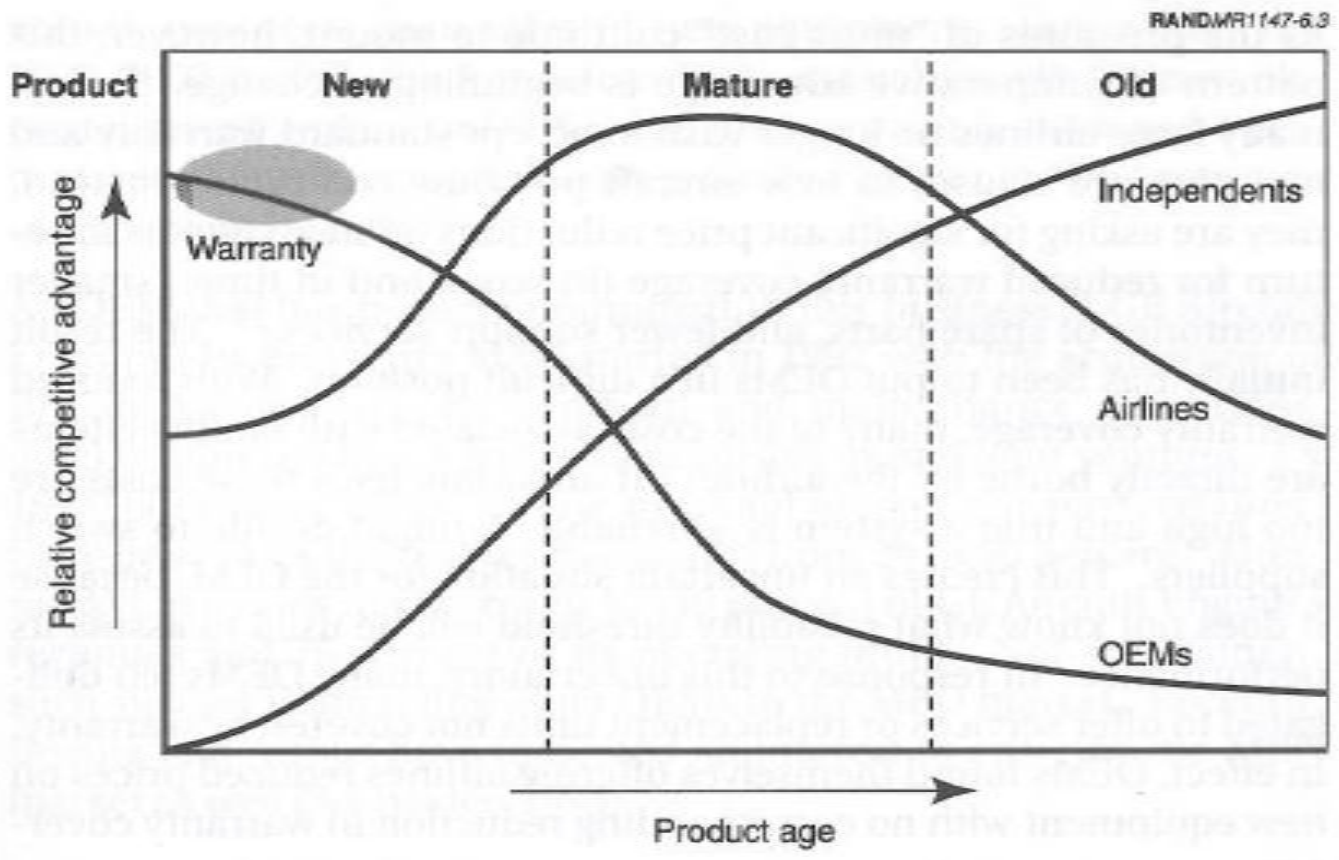

Source: Lorrell et al. (2000: 129)

Figure 6

T-45 Engine Costs: Power-by-the-hour ${ }^{\circledR}$ v. Original

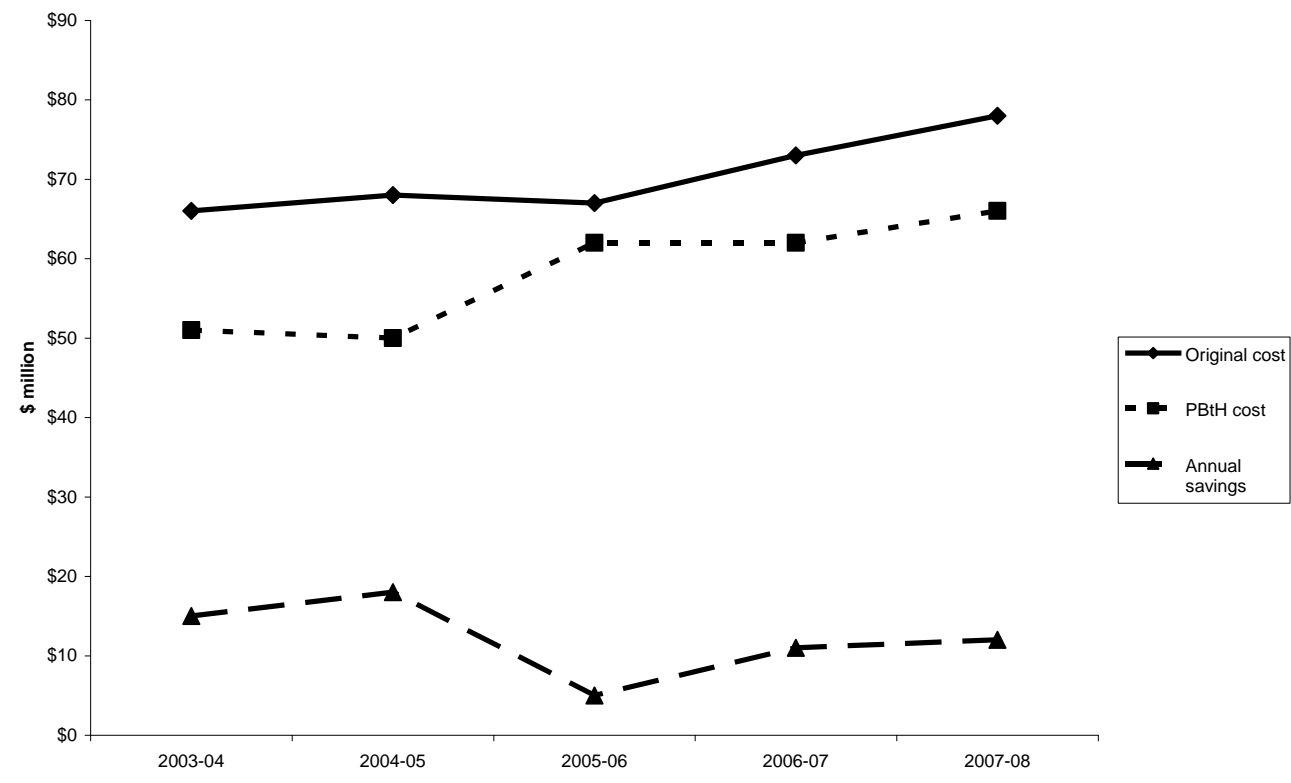

Note: Power-by-the-hour ${ }^{\circledR}$ costs for 2006 and 2007 are estimates Source: Kratz (2008) 
Figure 7

Rolls-Royce’s Total/Service Revenue 2000-10 (£m)

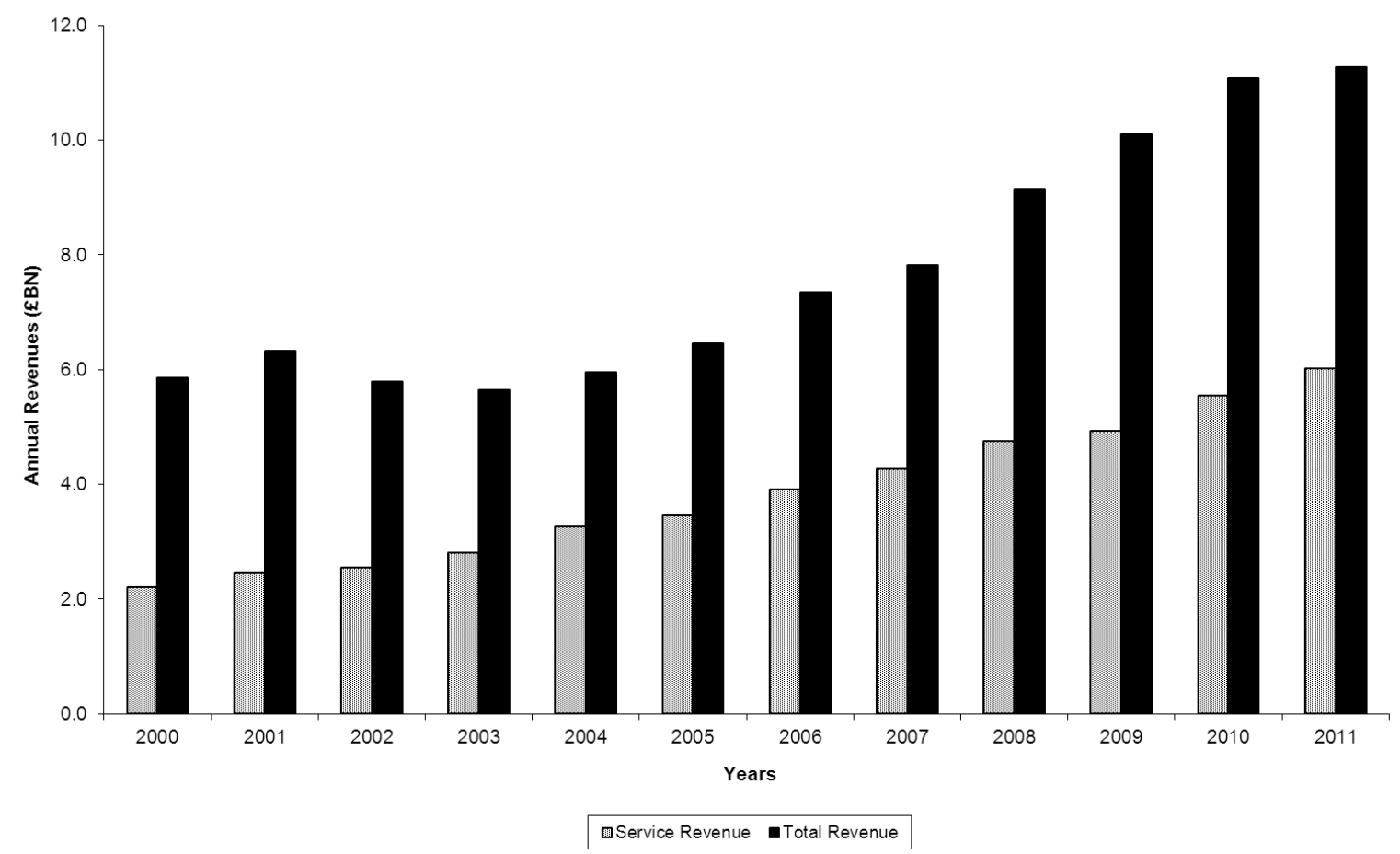

Source: Rolls-Royce Annual Reports 2000-2011 
Table 1

Comparative Performance of Rolls-Royce engines

\begin{tabular}{|c|c|c|}
\hline & $\begin{array}{c}\text { Conway } \\
\text { RCo.12 } \\
(\mathbf{1 9 6 0 )}\end{array}$ & $\begin{array}{c}\text { Trent } \\
892 \\
(\mathbf{1 9 9 8})\end{array}$ \\
\hline Application & Boeing 707 & Boeing 777 \\
\hline $\begin{array}{l}\text { Max. thrust } \\
\text { (lbs.) }\end{array}$ & 17,500 & 91,500 \\
\hline $\begin{array}{l}\text { Engine weight } \\
\text { (lbs.) }\end{array}$ & 5,147 & 16,000 \\
\hline $\begin{array}{l}\text { Bypass } \\
\text { ratio }\end{array}$ & $0.3: 1$ & $6.5: 1$ \\
\hline $\begin{array}{l}\text { Turbine inlet } \\
\text { temperature } \\
(T E T)\left({ }^{\circ} C\right)\end{array}$ & 1,050 & 1,750 \\
\hline $\begin{array}{l}\text { Specific Fuel } \\
\text { Consumption } \\
(\text { SFC) } \\
(\mathrm{lb} / \mathrm{hr} / \mathrm{lb})\end{array}$ & 0.87 & 0.575 \\
\hline $\begin{array}{l}\text { Pressure } \\
\text { ratio }\end{array}$ & $15: 1$ & 40.8:1 \\
\hline $\begin{array}{l}\text { Thrust;weight } \\
\text { ratio }\end{array}$ & $3.4: 1$ & $5.7: 1$ \\
\hline
\end{tabular}

Sources: Davis (2010); Gunston (1995); Kay (2007); Owen (2001); 
Table 2

Rolls-Royce's Principal MRO related collaborations

\begin{tabular}{|c|c|c|c|c|}
\hline Year & Venture & Form & Partner & Location \\
\hline 1996 & $\begin{array}{l}\text { Hong Kong Aero Engine } \\
\text { Services Ltd (HAESL) }\end{array}$ & JV & HAECO & China \\
\hline 1998 & $\begin{array}{l}\text { Texas Aero Engine Services Ltd } \\
\text { (TAESL) }\end{array}$ & JV & American Airlines & USA \\
\hline 1998 & $\begin{array}{l}\text { International Aero Engine } \\
\text { Component Overhaul (IECO) } \\
\text { Pte Ltd }\end{array}$ & JV & Singapore Int. Airlines & Singapore \\
\hline 1998 & Data Systems \& Solutions & JV & $\begin{array}{l}\text { Science Applications } \\
\text { International Corp. }\end{array}$ & UK \\
\hline 1999 & National Airmotive & Acquisition & $\mathrm{n} / \mathrm{a}$ & USA \\
\hline 2004 & N3 Engine Overhaul Services & $\mathrm{JV}$ & Lufthansa Technik AG & Germany \\
\hline
\end{tabular}

Source: Pugh (2002); Rolls-Royce Annual Reports 1994-2004

Djs/Re-shaping Business Strategy_v1.6/11.09.12 